\title{
Reversible operation of a pressurized solid oxide cell stack using carbonaceous gases
}

\author{
Jensen, S. H.; Langnickel, H.; Hintzen, N.; Chen, M.; Sun, X.; Hauch, A.; Butera, G.; Clausen, L. R.
}

Published in:

Journal of Energy Storage

Link to article, DOI:

10.1016/j.est.2019.02.003

Publication date:

2019

Document Version

Peer reviewed version

Link back to DTU Orbit

Citation (APA):

Jensen, S. H., Langnickel, H., Hintzen, N., Chen, M., Sun, X., Hauch, A., Butera, G., \& Clausen, L. R. (2019).

Reversible operation of a pressurized solid oxide cell stack using carbonaceous gases. Journal of Energy Storage, 22, 106-115. https://doi.org/10.1016/j.est.2019.02.003

\section{General rights}

Copyright and moral rights for the publications made accessible in the public portal are retained by the authors and/or other copyright owners and it is a condition of accessing publications that users recognise and abide by the legal requirements associated with these rights.

- Users may download and print one copy of any publication from the public portal for the purpose of private study or research.

- You may not further distribute the material or use it for any profit-making activity or commercial gain

- You may freely distribute the URL identifying the publication in the public portal 


\title{
Reversible Operation of a Pressurized Solid Oxide Cell Stack Using Carbonaceous Gases
}

\author{
S. H. Jensen*, H. Langnickel*, N. Hintzen*, M. Chen*, X. \\ Sun*, A. Hauch*, G. Butera**, L. R. Clausen** \\ *Department of Energy Conversion and Storage, Technical \\ University of Denmark, Frederiksborgvej 399, 4000 Roskilde \\ **Department of Mechanical Engineering, Technical University of \\ Denmark \\ Nils Koppels Allé, B. 403, 2700 Lyngby \\ Technical University of Denmark
}

\begin{abstract}
Low energy conversion efficiency and high storage costs still hamper a successful implementation of sustainable energy systems. Recent theoretical studies show that reversible electrochemical conversion of $\mathrm{H}_{2} \mathrm{O}$ and $\mathrm{CO}_{2}$ to $\mathrm{CH}_{4}$ inside pressurized solid oxide cells combined with subsurface storage of the produced gases can facilitate seasonal electricity storage with a round-trip efficiency reaching $80 \%$ and a storage cost below 3 $c / k W h$. Here we present test results with a 30-cell SOFCMAN 301 stack operated with carbonaceous gases at $18.7 \mathrm{bar}$ and $700{ }^{\circ} \mathrm{C}$ in both electrolysis and fuel cell mode. In electrolysis mode the $\mathbf{C H}_{4}$ content in the stack outlet gas increased from $0.22 \%$ at open circuit voltage to $18 \%$ at a current density of $\mathbf{- 0 . 1 7} \mathrm{A} \mathrm{cm}^{-2}$. The degradation observed by scanning electron microscopy studies correlate well with the observed electrochemical stack degradation. The degradation rates in both fuel cell and electrolysis mode were comparable to previously reported SOFCMAN stack degradation rates measured at ambient pressure operation with $\mathrm{H}_{2} / \mathrm{H}_{2} \mathrm{O}$ gas mixtures.
\end{abstract}

\section{Introduction}

With the displacement of fossil fuels by intermittent renewable sources such as wind and solar power the need increases for seasonal electricity storage [1] and production of renewable transportation fuels [2]. In this context the Solid Oxide Cell (SOC) technology is interesting due to its potentially high conversion efficiency and fuel flexibility in power-to-gas (P2G) $[3,4]$ and gas-to-power (G2P) systems [5, 6]. However, the efficiency of hydrogen-based storage is rather low, partly due to thermodynamic constraints [7]. In contrast much higher conversion efficiencies can be obtained with pressurized SOCs operated with methane rich gases [8]. A system round-trip efficiency (electricity-gas-electricity) exceeding $70 \%$ can be reached [9], and several modeling studies have been undertaken to optimize operation conditions for similar pressurized methane-based reversible SOC systems [10,11]. Coupled with pressurized subsurface gas storage such systems may enable storage cost around $3 \notin / \mathrm{kWh}$, i.e., comparable to pumped hydro [12].

An extensive body of literature address modelling of methane-based SOC systems for P2G and/or G2P, but papers dedicated to experiments with pressurized planar solid oxide cells and stacks are scarce, possibly due to the considerable technological challenges related to such tests [13]. Seal compression, pressure balancing, stable gas flow rates, controlled fuel utilization, and proper thermal management of the cell/stack as well as of the entire system are some of the related challenges [14].

Recently, iV curves and impedance spectra for an anodesupported Ni-YSZ|YSZ|LSM-GDC button cell operated at 1-5 atm and $750-850{ }^{\circ} \mathrm{C}$ with hydrogen and air to the fuel and air electrode respectively were investigated [15]. The area-specific resistance (ASR) was observed to decrease with increasing pressure, most significantly at the lower temperature because the pressure-dependent electrode resistances increasingly dominate the ASR with decreaing temperature.

LSM-YSZ and LSCF-YSZ electrodes on symmetrical cells were studied at oxygen partial pressure $\mathrm{pO}_{2}$ from 0.1 to $10 \mathrm{~atm}$ by impedance spectroscopy [16]. Overall, the electrode resistance was reduced by a factor of $\sim 2$ by increasing the oxygen pressure from a nominal $0.2 \mathrm{~atm}$ (air) to $10 \mathrm{~atm}$.

Co-electrolysis of $\mathrm{H}_{2} \mathrm{O}$ and $\mathrm{CO}_{2}$ has been investigated with a Ni-YSZ|YSZ|GDC-LSCF button cell at pressures from 1-10 bar [17]. The gas analyses revealed that methane was formed when the cell was pressurized and polarized in electrolysis mode, and that mass transfer limitation through the porous electrode prevented the gas from fully reaching thermodynamic equilibrium. Similar to a previous single-cell study conducted at atmospheric pressure [18] it was concluded that the kinetics of the catalytic $\mathrm{CH}_{4}$ formation (and internal reforming) on the $\mathrm{Ni}$ YSZ electrode only to a limited degree prevent the gas from reaching equilibrium.

A comparison of the pressure dependence of the performance of an anode supported cell (ASC) and an electrolyte supported cell (ESC) was provided by Hsieh et al. [19]. The ASC had a NiYSZ fuel electrode whereas the ESC had a Ni-GDC electrode. Both cells were equipped with LSM-YSZ air electrodes. The ESC had a 3 YSZ 80-110 $\mu \mathrm{m}$ thick electrolyte whereas the ASC had a 4-6 $\mu \mathrm{m}$ thick $8 \mathrm{YSZ}$ electrolyte. When increasing pressure from 1 to $5 \mathrm{~atm}$, the ASC exhibited a much larger increase in power density than the ESC. The measured electrochemical 
impedance spectra (EIS) revealed that this could be attributed to the lower ohmic resistance of the pressure-independent electrolyte for the ASC compared with that of the ESC.

Bernadet et al. [20] tested two commercial single cells with a diameter of $35 \mathrm{~mm}$ at $1-10 \mathrm{~atm}$. The cells were NiYSZ|YSZ|GDC| half-cells with respectively an LSCF and an LSC air electrode. Based on the measured iV curves and a microstructural analysis of the cells, a deconvolution as function of current density and pressure was provided for the two cells.

The performance of a $5 \times 5 \mathrm{~cm}^{2}$ Ni-YSZ|YSZ|LSM-YSZ cell was examined at 1-15 atm by Sun et al. [21] with various $\mathrm{H}_{2} / \mathrm{H}_{2} \mathrm{O}$ ratios. Both impedance and $\mathrm{i}-\mathrm{V}$ curves were measured to confirm decreasing electrode resistance and increasing open curcuit voltage. The cell was sealed with glass and interestingly no significant pressure dependence of the measured leak rate was observed.

Santhanam et al.[22] conducted a pressure test from 1.4-8 bar on a commercially available SOC stack with 10 ESCs. A model was provided describing the temperature change in the stack as function of endothermal/exothermal conversion of $\mathrm{H}_{2} \mathrm{O}$ to/from $\mathrm{H}_{2}$. Based on the model, the maximum achievable round-trip efficiency was discussed.

Jensen et al. [14] recently conducted a pressure test from 125 bar with an 11-cell SOC stack where each ASC had an active electrode area of $87.8 \mathrm{~cm}^{2}$. The test provided iV curves, leak rates and impedance as function of pressure. In addition the stack was tested for $200 \mathrm{~h}$ at 10 bar to assess degradation rates when operated in electrolysis mode using $\mathrm{H}_{2} \mathrm{O} / \mathrm{H}_{2}$ as inlet gas for the fuel electrodes. The stack was demonstrated to survive a full pressure and thermal cycle, and to have a degradation rate comparable to that of stacks tested at ambient pressure. Above 3 bar steam condensation negatively affected the operation stability. In a later stack test this was resolved by heat tracing of the gas pipes [23].

Finally, pressurized operation up to 15 bar has been reported with a prototype of a larger stack with $30 \mathrm{ESCs}$, each with an active electrode area of $127.8 \mathrm{~cm}^{2}$, and a nominal DC input power of $10 \mathrm{~kW}$ supplied to the electrolysis stack [13]. Thermal management and heat losses to the surroundings were some of the observed challenges to be addressed in future experiments.

The results presented in this paper addresses one of the major challenges related to an efficient upscaling of sustainable energy systems: Efficient conversion and storage of renewable electricity. More specifically it is demonstrated that it is possible to reversibly convert methane inside a pressurized planar solid oxide cell stack. This represents an important step towards realizing cost- and conversion-efficient large-scale electricity storage systems utilizing existing natural gas infrastructures [12] since the thermodynamics of methane conversion potentially enables storing electricity with an efficiency exceeding $70 \%$ [9]. In contrast the efficiency is limited to around $50 \%$ when based on hydrogen conversion [7].

\section{Material and Methods}

An SOFCMAN 301 stack with 30 NiO-YSZ|YSZ|GDC |LSCF-GDC cells $[24,25]$ having $63 \mathrm{~cm}^{2}$ active electrode area per cell was operated in a dedicated pressure test setup. The stack design is outlined in Fig. 1.

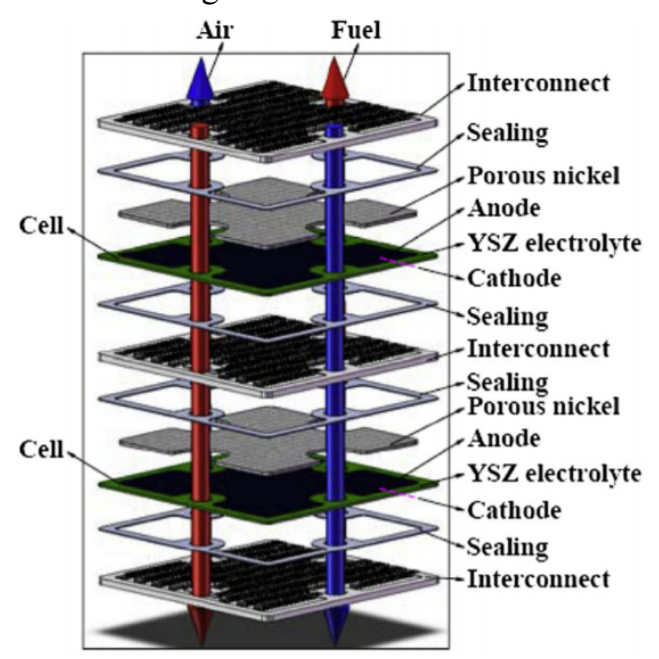

Fig. 1. Sketch of the internal structure in a 30-cell SOFCMAN. Figure taken from reference [26].

The test setup is sketched in Fig. 2 and described in detail elsewhere [23]. $0.8 \mathrm{~mm}$ thick sheets of Thermiculite ${ }^{\circledR} 866$ were used to seal the stack and compression/gas manifold plates. A compression force of $300 \mathrm{~kg}$ was applied using a spring-load (not shown in Fig. 2).

First the stack was heated to $750{ }^{\circ} \mathrm{C}$ followed by reduction of the $\mathrm{NiO}$ in the fuel electrodes. Subsequently the temperature was reduced to $700{ }^{\circ} \mathrm{C}$. The following stack test was conducted in four consecutive parts. Gas compositions for the central measurements in each part are specified in Table 1. Afterwards a scanning electron microscope (SEM) study was carried out.

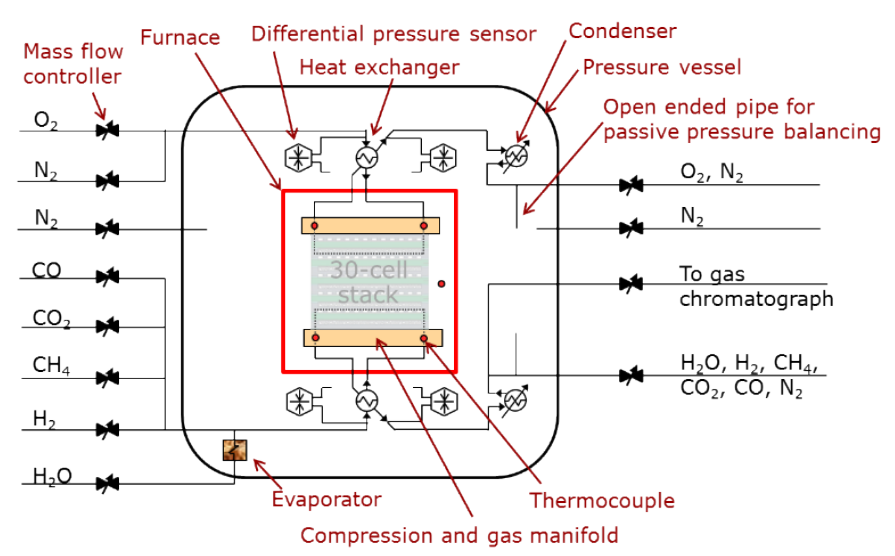

Fig. 2. Test setup used for pressurized operation of a 30-cell stack from SOFCMAN.

The central measurements in each part of the test are briefly described below. 
Part A: The pressure was increased in four steps from 1 to 18.7 bar. Impedance spectra and iV curves were recorded at each step. Impedance was measured with a Solartron 1260 in combination with a Kepco 4-50 bipolar power supply. A Delta Electronica SM6000 power supply and a EA 80-600 Electronic load was used to control the current to the stack. The pressure drop across the stack and heat exchangers was measured during pressurization using APR-2000ALW differential pressures sensors.

Part B: An equilibrium fuel gas mixture (neglecting higher hydrocarbons than $\mathrm{CH}_{4}$ ) with an $\mathrm{H} / \mathrm{C}$ ratio of 7 was fed to the stack. The inlet composition, and the outlet composition at open circuit voltage (OCV) as well as at current densities of $-0.09 \mathrm{~A}$ $\mathrm{cm}^{-2}$ and $-0.17 \mathrm{~A} \mathrm{~cm}^{-2}$ was measured with an Agilent micro gas chromatograph (GC) 490 with a Molsieve $5 \AA$ and a PoraPlot Q column. Helium was used as a carrier gas.

Part C: The oxygen concentration at the air side was reduced to minimize oxygen leaking from the air side to the fuel side. Subsequently the stack was operated at $-0.10 \mathrm{~A} \mathrm{~cm}^{-2}$ for about 100 hours.

Part D: Next the stack was operated in fuel cell mode. Inlet gas composition and the stack outlet gas composition were measured at $\mathrm{OCV}, 0.09 \mathrm{~A} \mathrm{~cm}^{-2}$ and $0.15 \mathrm{~A} \mathrm{~cm}^{-2}$. The stack was operated at $0.09 \mathrm{~A} \mathrm{~cm}^{-2}$ for about 12 hours.

The current density was chosen to keep the cell polarization within $100-200 \mathrm{mV}$ to reflect operating conditions adequate for high round-trip efficiencies. With a decrease in internal resistance higher current densities can be obtained while keeping the cell polarization constant.

Table 1 Gas flow rates in Normal Liters Per Hour (NLH) during test

\begin{tabular}{|c|c|c|c|c|c|c|c|}
\hline \multirow[t]{2}{*}{ Test Part } & \multicolumn{5}{|c|}{ Fuel side } & \multicolumn{2}{|c|}{ Air side } \\
\hline & $\mathrm{H}_{2}$ & $\mathrm{H}_{2} \mathrm{O}$ & $\mathrm{CO}$ & $\mathrm{CO}_{2}$ & $\mathrm{CH}_{4}$ & $\mathrm{O}_{2}$ & $\mathrm{~N}_{2}$ \\
\hline $\mathbf{A}$ & 200 & 200 & 0 & 0 & 0 & 126 & 474 \\
\hline B & 31.5 & 140 & 6.2 & 36.8 & 1.3 & 126 & 474 \\
\hline C & 31.5 & 140 & 6.2 & 36.8 & 1.3 & 40 & 1800 \\
\hline D & 64.2 & 40.9 & 5.9 & 6.1 & 42.1 & 170 & 1800 \\
\hline
\end{tabular}

\section{Results}

The test results are presented with reference to the parts of the overall test outlined in Table 1.

\subsection{Pressure drop, iV and Impedance as Function of Pressure}

In Part A (Table 1), the relative inlet and outlet pressure of both the fuel and oxidative gases was measured against the pressure in the autoclave using differential pressure sensors (Fig. $2)$. Fig. 3 shows the pressure drop $(d P)$ across the stack and heat exchangers, calculated as the difference between the inlet and outlet pressures. The air flow to the stack was kept constant during the entire measurement whereas the fuel flow was varied above 3 bar.

iV curves were recorded at 1, 3, 10 and 18.7 bar. The iV curves are presented in Fig. 4(a). Surprisingly, the slope of the
iV curves did not gradually decrease with increasing pressure. This is reflected by the almost constant average cell resistance (ASR) shown in Fig. 4(b).

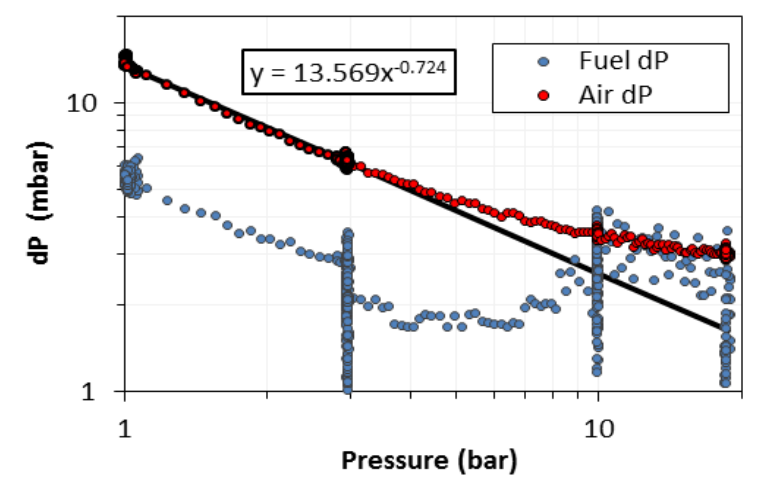

Fig. 3. Pressure drop across the SOFCMAN stack and heat exchangers as function of pressure. The air $d P$ between 1 and 3 bar is fitted with a power law expression. The inset shows the power law expression.

The measured average cell OCV is shown in the inset in Fig. 4(a). As found in previous stack tests, the difference between the theoretical cell OCV (the line) and the measured average cell OCV (the dots) increases with pressure[23]. Based on the measured $\mathrm{OCV}$ the $\mathrm{H}_{2} \mathrm{O}$ concentration (with $\mathrm{H}_{2}$ as balance) was $52.2,55.5,57.6$, and $57.9 \%$ at respectively $1,3,10$ and 18.7 bar.
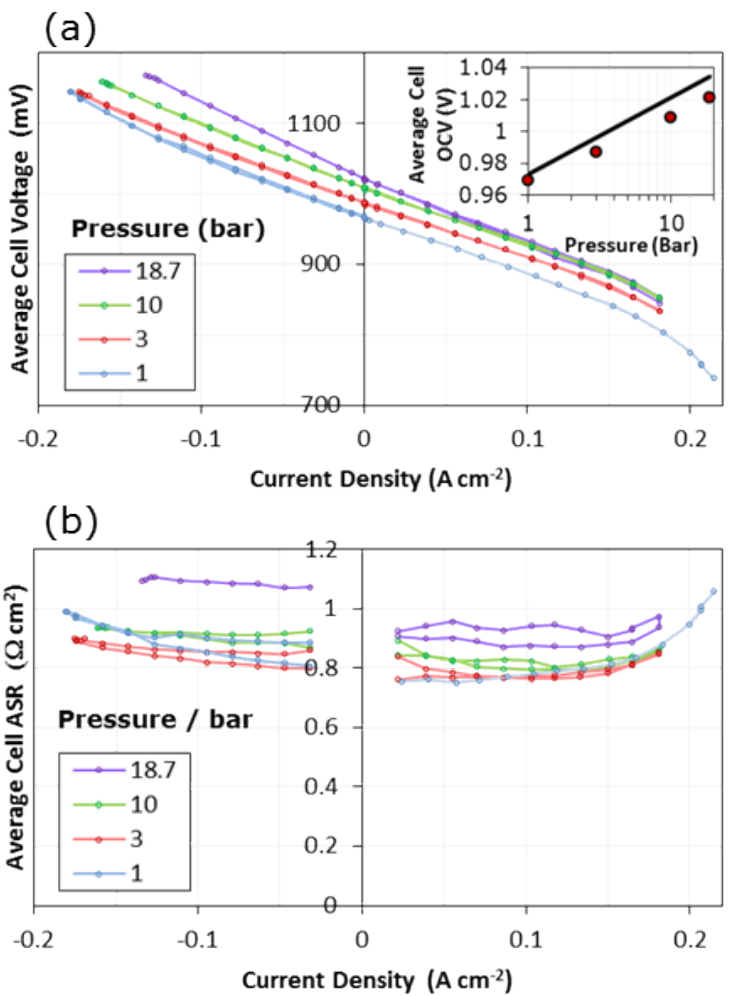

Fig. 4. (a) SOFCMAN stack iV curves recorded at various pressures. The inset show the OCV vs. pressure. The red dots are measured stack OCV divided with the number of cells in the stack. The line is the theoretical Nernst cell voltage. (b) Average cell ASR. 
The ASR in Fig. 4(b) is calculated as the voltage difference between stack OCV and the stack voltage at the given current, divided by the current, the number of cells in the stack and the active electrode area.

Stack impedance spectra were recorded at OCV just before and after the $\mathrm{iV}$ curve measurements. The impedance spectra are presented in Fig. 5. Note how the size of electrode arc (high frequency part) decreases with increasing pressure. The electrode polarization (here taken as difference in the real part of the impedance at $2.5 \mathrm{kHz}$ and $9.6 \mathrm{~Hz}$.) was respectively 125,83 , $63,54 \mathrm{~m} \Omega \mathrm{cm}^{2}$ at $1,3,10,18.7$ bar. In contrast the ohmic resistance seems to fluctuate with pressure. The low-frequency intercept with the $\mathrm{x}$-axis was obtained by modeling the lowfrequency arc in the frequency range from $0.1 \mathrm{~Hz}$ to $1.7 \mathrm{~Hz}$ with an RC-circuit in series with a resistor. At 1, 3, 10 and 18.7 bar the resistance was respectively $1.25,1.37,1.28$ and $1.51 \Omega \mathrm{cm}^{2}$.
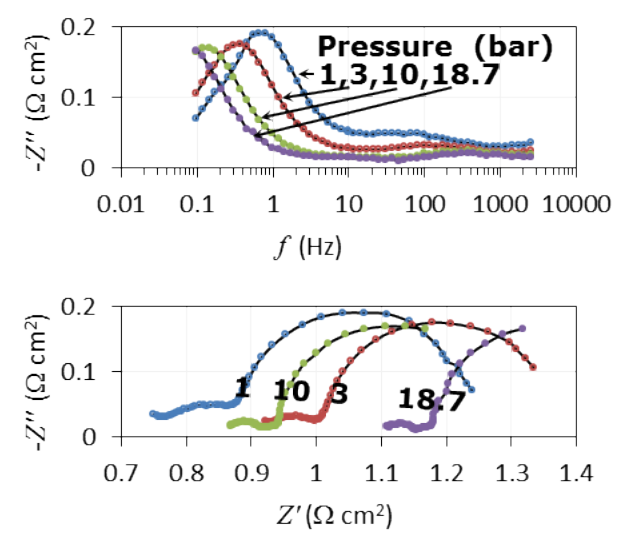

Fig. 5. (a) Bode plot and (b) Nyquist plot of impedance spectra recorded at 1,3,10 and 18.7 bar with the gas composition in Table 1, Test Part A.

\subsection{Internal Methanation in the Stack}

After the pressurization, iV and impedance measurements in Test Part A, the stack was operated with a carbonaceous gas supplied to the fuel electrodes and air to the air electrodes (Table 1, Test Part B). The fuel inlet gas composition is the equilibrium composition at 18,7 bar, $700{ }^{\circ} \mathrm{C}$, neglecting higher hydrocarbons than $\mathrm{CH}_{4}$. The inlet gas composition was analyzed using the $\mathrm{GC}$ and used as calibration for the measurement of the outlet gas compositions.

The GC measurements revealed $\sim 20 \mathrm{vol} \% \mathrm{~N}_{2}$ in the stack fuel outlet gas. The dry equilibrium gas composition corrected for the $\mathrm{N}_{2}$ content and neglecting higher hydrocarbons than $\mathrm{CH}_{4}$ is presented in Fig. 6(a). Importantly the measured $\mathrm{CH}_{4}$ concentration in the outlet gas increased from $0.22 \mathrm{vol} \%$ at OCV to $18 \mathrm{vol} \%$ at $-0.17 \mathrm{~A} \mathrm{~cm}^{-2}$. The lines show the equilibrium concentration adjusted for the Faradaic removal of O-atoms. The equilibrium concentration was calculated with Factsage 7.1.

The $\mathrm{N}_{2}$ measured with the GC most likely entered the fuel gas from the air electrodes via leaks in the electrolytes (and seal). The oxygen from the air leak partially oxidizes the fuel. Further, the oxygen concentration in the air electrode increases near the electrolyte/electrode interface. Hence, the oxygen leak is expected to increase with increasing electrolysis current density. In Fig. 6(b), the measured gas concentrations are corrected for the estimated fuel gas oxidation by shifting the measurement points to the right on the $\mathrm{x}$-axis to account for an additional parasitic current density related to the oxygen leak. Specifically, the adjusted current density used to present the measurement points in Fig. $6(\mathrm{~b})$ is calculated as $i_{a d j}=c_{1}+c_{2} \cdot i_{m}$ where $i_{m}$ is the actually measured current density (presented in Fig. 6(a) and $c_{1}$ and $c_{2}$ are fitting constants obtained by minimizing the sum of errors between the measured (dots) and calculated (line) $\mathrm{CO}_{2}$ concentration.

With the correction for the internal leak, it can be observed that the outlet gas approximately reaches the equilibrium composition before it exits the stack. Arguably, part of the measured deviation from equilibrium concentration also relates to kinetic limitations of the methane formation, although this deviation is expected to be of less importance $[17,18]$. This point is further discussed in Section 4.2.
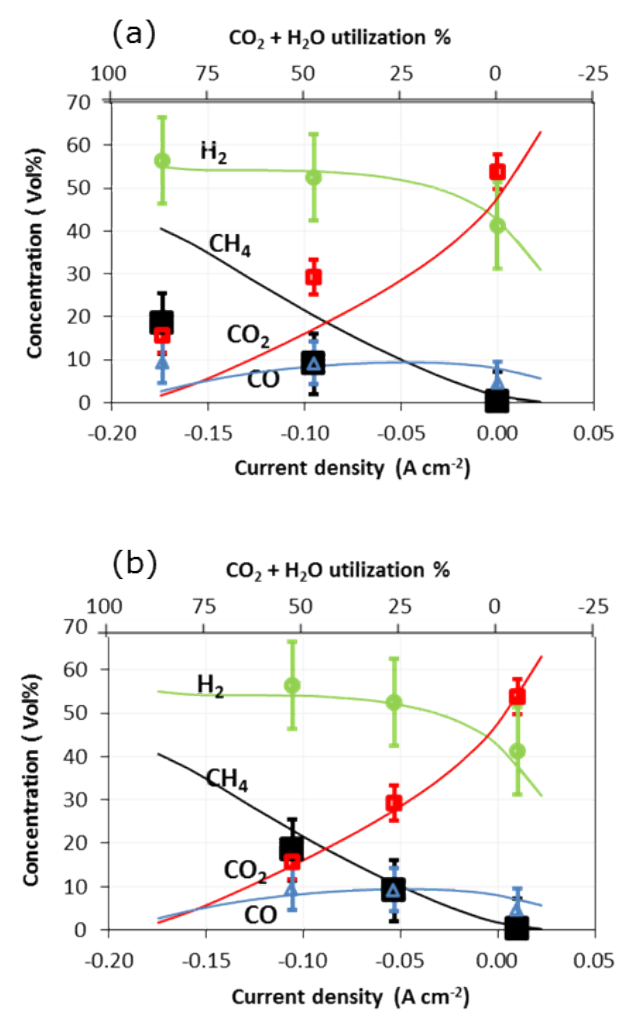

Fig. 6. (a) measured gas composition (dots) as function of electrolysis current density. (b) Same gas compositions as above but shifted on the $\mathrm{x}$-axis to correct for an internal leak in the stack. Lines in (a) and (b) represent the theoretical equilibrium concentration calculated using Factsage 7.1 corrected for the Faradaic current, i.e. the supply/removal of O-atoms to/from the gas in fuel cell/electrolysis mode (positive/negative current density). The concentrations are shown after removal of $\mathrm{H}_{2} \mathrm{O}$ and an $\mathrm{N}_{2}$ leak. Uncertainty bars reflect the $\mathrm{GC}$ measurement uncertainty. 


\subsection{Long-term Electrolysis Test}

A substantial increase in the internal leak in the stack was observed after the measurements presented in Fig. 6. In order to continue the stack test the oxygen concentration at the air side was reduced to minimize oxygen leaking to the fuel side.

In Test Part $\mathrm{C}$, the stack voltage was measured as function of electrolysis test time (Fig. 7). During the test, the stack was exposed to a pressure cycle. The pressure cycle did not affect the stack OCV (not shown) and the stack voltage reached the same level as before the pressure cycle after a few hours of operation at $-0.10 \mathrm{~A} \mathrm{~cm}^{-2}$. The stack voltage as a function of time gradually increased at a rate of $14 \%$ per 1000 hours (green line in the figure).

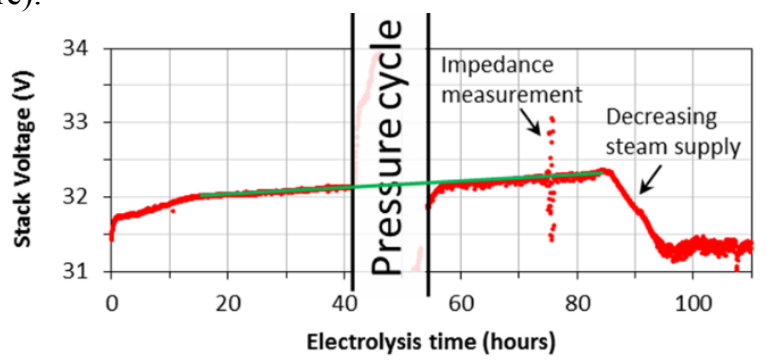

Fig. 7. Stack voltage during electrolysis operation at $-0.10 \mathrm{~A} \mathrm{~cm}^{-2}$ operated with the gas flow rates specified in Test Part C, Table 1. At the end, the steam supply gradually decreased to $84 \mathrm{NLH}$. The green line indicates the trend in the voltage in electrolysis mode during stable operation.

At the end of Test Part C, a decreasing steam supply caused a decreasing stack voltage. At the same time the fuel gas inlet and outlet temperature increased as shown in Fig. 8.
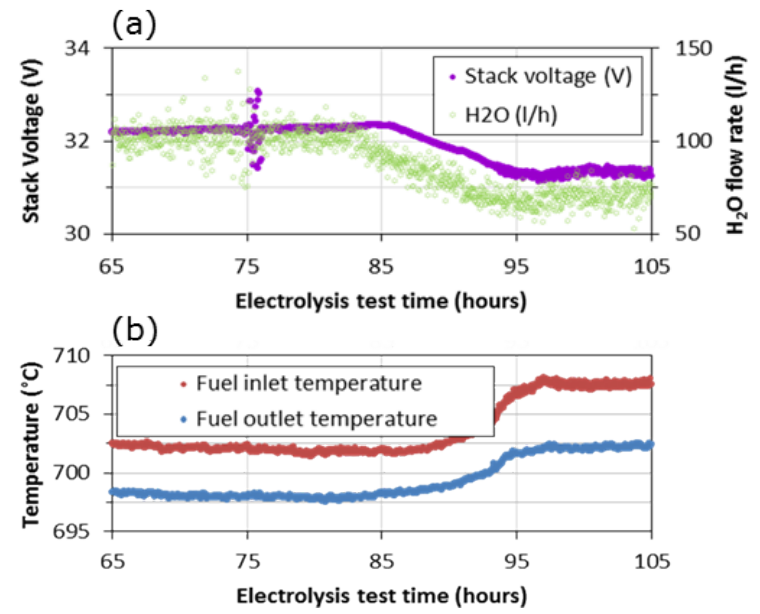

Fig. 8. (a) Stack voltage and steam flow rate, (b) fuel gas inlet and outlet temperature, during the last part of the electrolysis test shown in Fig. 7.

\subsection{Fuel Cell Operation and Internal Methane Reforming}

After the electrolysis operation presented in Fig. 7 and Fig. 8, the stack was operated in fuel cell mode at $0.09 \mathrm{~A} \mathrm{~cm}^{-2}$ and 18.7 bar with a methane-rich gas as specified in Table 1, Test Part D. The stack voltage as function of time is shown in Fig. 9. After the first five hours of operation the stack exhibited a degradation rate of $3.2 \%$ per 1000 hours (green line in Fig. 9).

The stack inlet and outlet gas composition at OCV were measured using the GC prior to the measurements presented in Fig. 9. The outlet gas composition was measured at $0.09 \mathrm{~A} \mathrm{~cm}^{-2}$ and $0.15 \mathrm{~A} \mathrm{~cm}^{-2}$ after, the voltage measurements presented in Fig. 9.

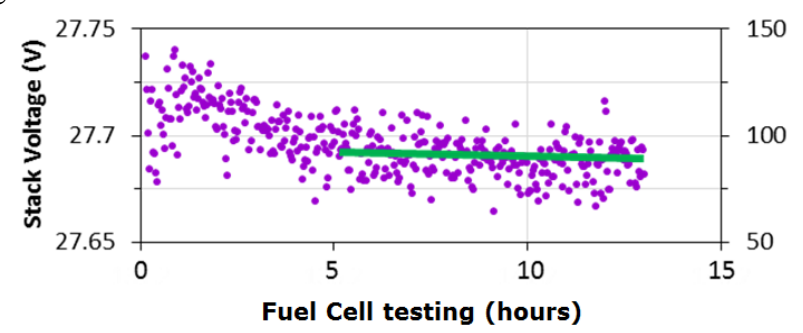

Fig. 9. Stack voltage as function of time at $0.09 \mathrm{~A} \mathrm{~cm}^{-2}$ and 18.7 bar operated with the gases shown in Table 1, Test Part D. The green line indicates the trend in the voltage after $5 \mathrm{~h}$ test in fuel cell mode.

The $\mathrm{H}_{2}$ measurement signal is not used for the calculation of the gas concentrations due to major uncertainties in measured $\mathrm{H}_{2}$ concentration signal. Instead the theoretical equilibrium $\mathrm{H}_{2}$ concentration is used for to obtain the gas concentrations. As for Fig. 6(a), the dry gas concentration corrected for $\mathrm{N}_{2}$ is presented function of current density in Fig. 10. The figure shows a decreasing $\mathrm{CH}_{4}$ and increasing $\mathrm{CO}_{2}$ concentration with increasing fuel cell current density. The presence of $\mathrm{N}_{2}$ in the fuel gas indicates oxygen leaking from the air electrode to the fuel electrode. Air (with an oxygen content of $21 \%$ ) was used as oxidizing gas in the electrolysis test (Fig. 6). In the fuel cell test (Fig. 10) the oxygen content was reduced to $170 /(170+1800)=$ $9 \%$. This decreases the oxygen leak to the fuel electrodes. Adjusting for the additional parasitic current density related to the oxygen leak will move the points to the left in the figure. However, it is evident that the deviation between the measured and equilibrium $\mathrm{CH}_{4}$ and $\mathrm{CO}_{2}$ concentrations cannot be explained by an oxygen leak through the electrolytes.

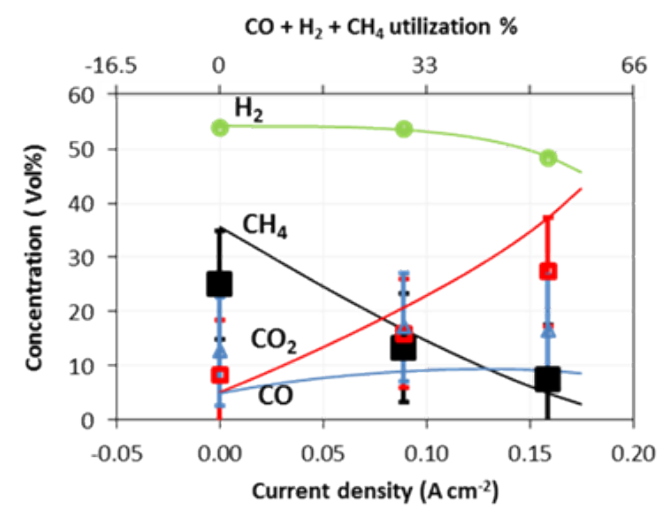

Fig. 10. Measured gas composition (dots) as function of fuel cell current density. The lines represent the equilibrium concentrations for the individual gases. Uncertainty bars reflect the $\mathrm{GC}$ measurement uncertainty. No uncertainty bars are given for the $\mathrm{H}_{2}$ concentrations since it is a calculated equilbrium concentration and not a meaured concentration. 
Due to a very high uncertainty for the $\mathrm{H}_{2}$ concentration measurements (low signal-to-noise level in the GC), the presented $\mathrm{H}_{2}$ concentration is not the measured concentration but the equilibrium concentration. This impacts the presented normalized concentrations for the remaining gases since the sum of the presented concentrations is normalized to $100 \%$. Consequently this increases the uncertainties which are reflected in the relatively large uncertainty bars.

\subsection{Post-mortem SEM}

Fig. 11 provide representative overview SEM images of cell 15 at contact points near the fuel gas inlet (a), middle part (b), and fuel gas outlet (c). The various layers/features in the stack are indicated with red arrows and text. Interconnect (IC) layers are seen in top and bottom of Fig. 11(a,b). At the fuel gas outlet the stack was cut at a gas channel explaining why no IC is seen (Fig. 11(c), bottom). Corrosion scales/protective coatings are observed on the IC surface on the air and to some extent on the fuel side. A cathode current collector (CC) layer is seen on top of the air electrode. The air electrode is separated from the electrolyte with a barrier layer. An anode ${ }^{i}$ current collector (AC) layer is sandwiched between the fuel electrode support layer and the IC. This is the porous Ni layer seen in Fig. 1. The insets show representative magnifications of (a) the electrolyte part at gas inlet, (b) the gap between CC and IC coat at center, (c) electrolyte and fuel electrode delamination at gas outlet.

Fig. 12 provides higher magnification SEM images of the fuel electrode/electrolyte interface for the middle part of cell 5 (a), middle part of cell 15 (b), and fuel outlet part of cell 15 (c). In (a) the approx. 10 micron thick fuel electrode can be distinguished from the support layer, by observing the particle size distribution in the two layers.

Multiple cells in the stack were investigated revealing the same type of damage visible in the two figures. The various generic types of damage observed in the SEM images are listed below:

1. Contact loss. On the air side, some contact loss seems to occur between the IC coating and the CC layer. Loss of contact is evident at the middle part, Fig. 11(b) whereas the interface seems intact for the inlet and outlet part, Fig. 11(a, c). On the fuel side, an oxidation scale can be observed between the Nickel AC layer and the IC. In Fig11c, the fuel electrode is not in direct contact with the IC so it cannot be concluded whether there is loss of contact here.

2. Vertical cracks in air electrode and electrolyte. At the fuel outlet, Fig. 11(c), several vertical lines of breakage can be observed in the oxygen electrode and electrolyte. Such cracks were also seen in other places, e.g., Fig. 11(a), inset.

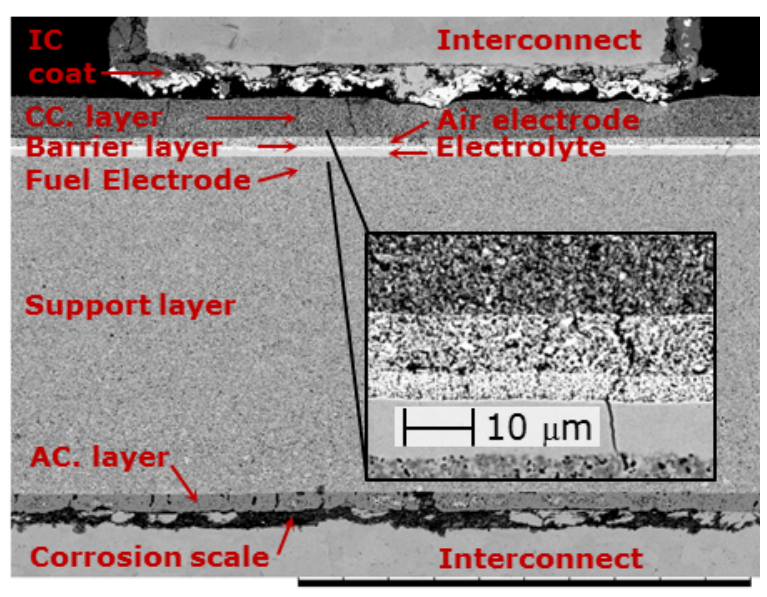

(a)
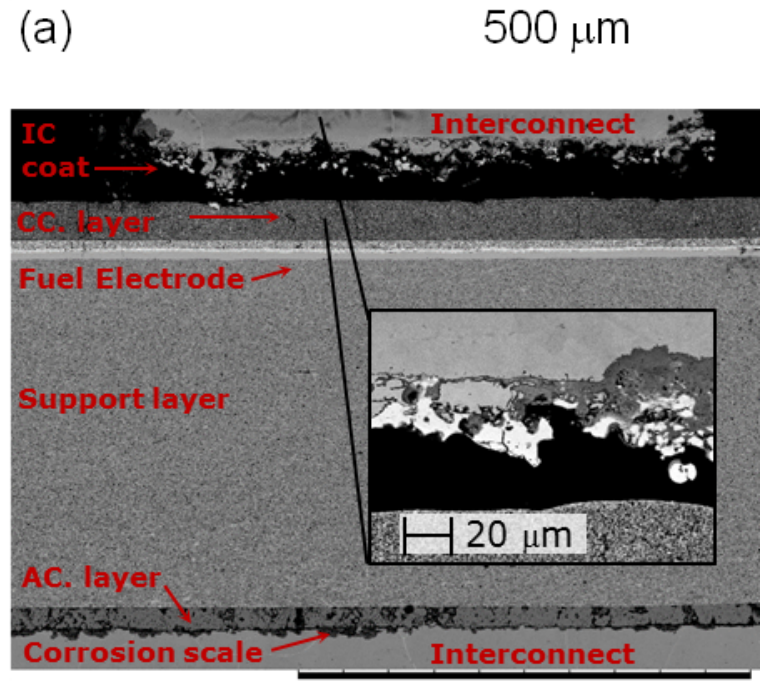

(b)

$$
500 \mu \mathrm{m}
$$

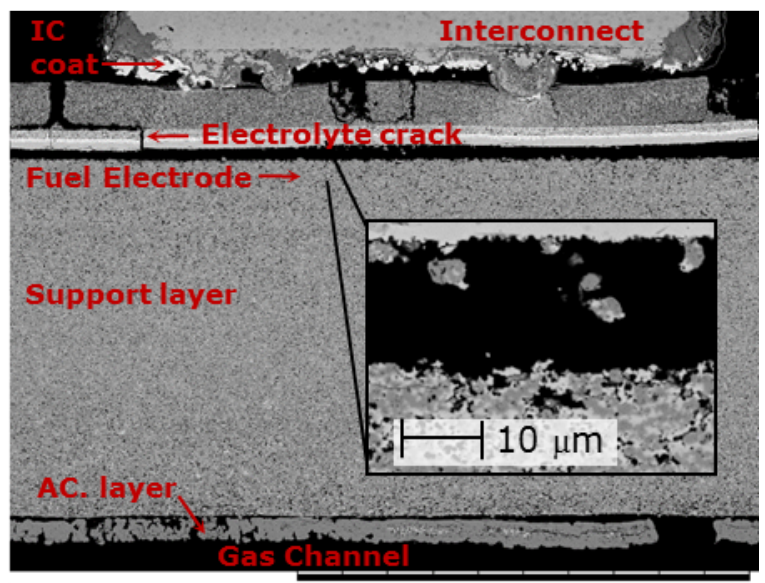

(c)

$$
500 \mu \mathrm{m}
$$

Fig. 11. Representative SEM overview images of cell 15 at contact points at fuel gas inlet (a), middle of the cell (b) and fuel gas outlet part of the cell (c). Interconnect/oxygen electrode contact in top part of each image.

${ }^{\text {i }}$ Referring to operation in fuel cell mode 
3. Delamination between electrolyte and fuel electrode. At the fuel gas outlet, the fuel electrode is delaminated from the electrolyte, Fig. 11(c) and Fig. 12(c). No delamination was seen in the inlet and middle part of the cell.

4. Fuel electrode oxidation. Fig. 12(a) provides an example of a "still-reduced" middle part of a cell with a structure that on a microstructure level appears intact. Fig. 12(b) shows an oxidized fuel electrode at the middle part of cell 15 . The oxidation of the outlet part of the fuel electrode, Fig. 12(c) is similar - perhaps even slightly less pronounced - to what was observed for the middle part of cell 15, Fig. 12(b).

\section{Discussion}

\subsection{Pressure drop, $i V$ and Impedance as Function of Pressure}

In Fig. 3 a continuously decreasing pressure drop with increasing pressure is observed for the air side. The air flow to the stack was kept constant during the entire measurement whereas the fuel flow was varied above 3 bar. The fluctuations in the fuel side $d P$ above 3 bar are most likely caused by condensation in the differential pressure sensor pipes. The iV curve measurements considerably affect the fuel $d P$ due to the condensation related change in $\mathrm{H}_{2} / \mathrm{H}_{2} \mathrm{O}$ concentration in the stack outlet gas.

The dependence of the air pressure drop on the pressure is not a simple power law (corresponding to a straight line in Fig. 3), indicating the pressure drop deviates from an isentropic pressure drop across the stack and heat exchangers [14, 23]. An isentropic air pressure drop should exhibit a power law dependence with an exponent of -0.71 [14].

The fit in Fig. 3 for low pressures gives an exponent of -0.724 , i.e. in relatively good agreement with theory. The deviation from the straight line above 3 bar is possibly related to a decreasing flow uniformity in the stack with increasing pressure [27]. Additionally, the air in the corners of each cell is likely more stagnant at high pressure than at low pressure [28] which would also decrease the measured exponent. Computational Fluid Dynamics (CFD) calculations could be used to investigate this further, but is beyond the scope of this paper.

The lower $d P$ at high pressure enables operation of stacks with larger foot prints since more gas can pass the gas channels at a certain maximum allowable pressure drop in the gas channels. In fact, to a first approximation the cell side length scales with the square root of the pressure [14]. This means that if the maximum cell side length achievable today in planar SOC stacks is $\sim 20 \mathrm{~cm}$, it could be $\sim 100 \mathrm{~cm}$ at 25 bar, thereby truly enabling MW SOC stacks!

The OCV in the inset in Fig. 4(a) shows an increasing difference with increasing pressure between the Nernst cell voltage and the measured average cell OCV. This has previously been observed, and explained as the result of electrolyte pinholes and/or gas leaks at the internal stack manifolds [14, 23]. The result emphasizes the importance of a

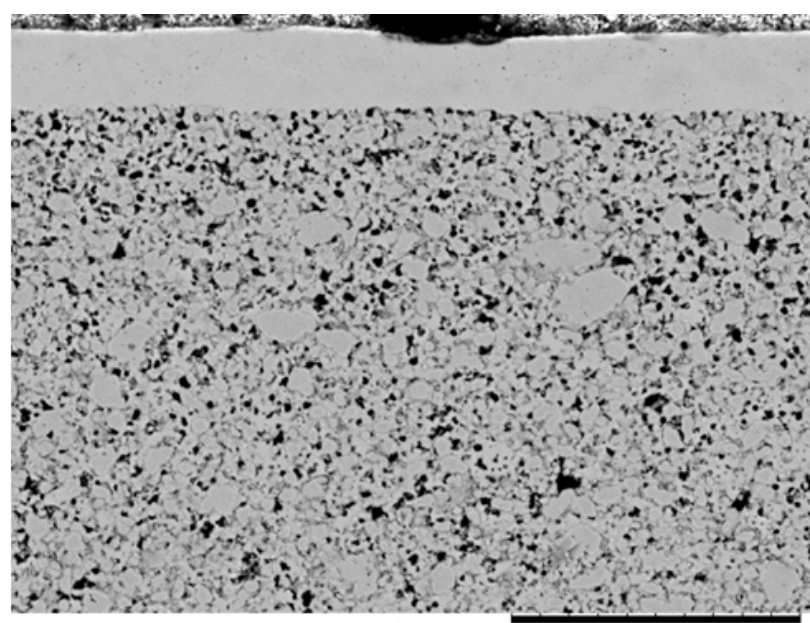

(a)
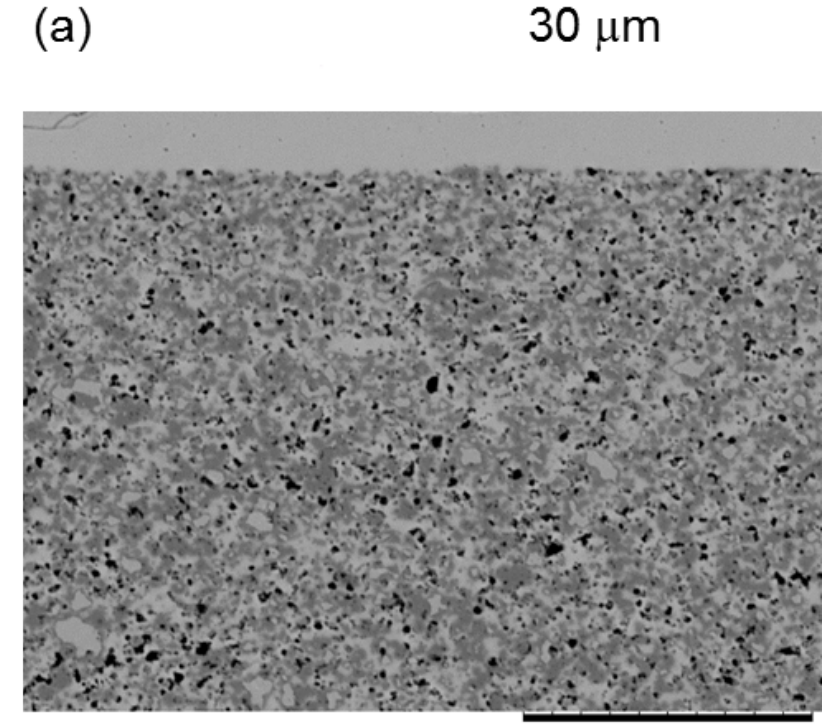

(b)

$30 \mu \mathrm{m}$

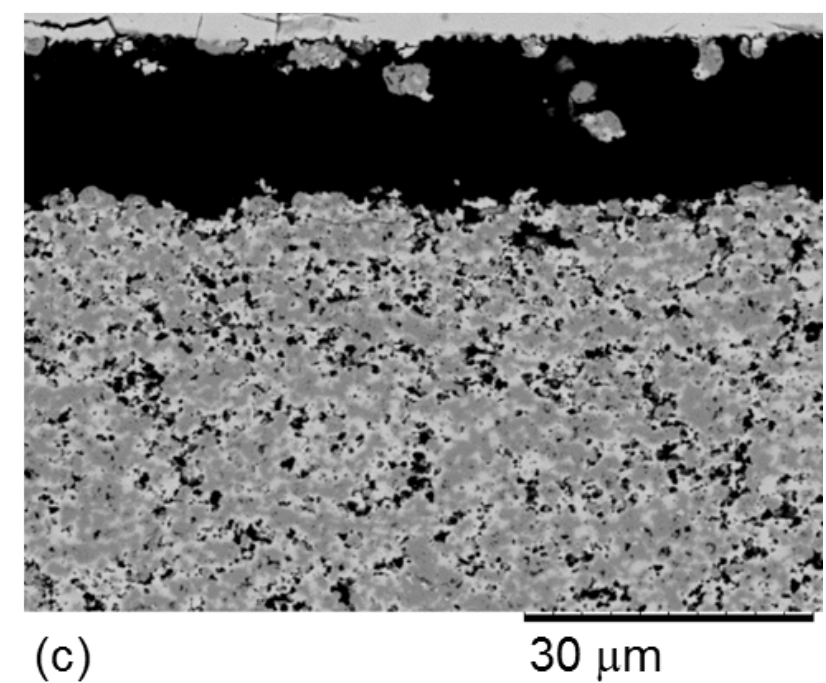

Fig. 12. Higher magnification SEM images of the middle part of cell 5 (a), middle part of cell 15 (b) and fuel outlet part of cell 15 (c). All images show electrolyte/fuel electrode interface part of the cells. 
careful minimization of gas leaks at the electrolytes and manifolds when designing stacks for pressurized operation. It should be noted that to some extent low flow uniformity could also lower the measured average cell OCV. however delamination of the fuel electrode is observed in (c).

In contrast to previously reported stack tests, the ASR did not systematically decrease with increasing pressure, Fig. 4(b). This is most likely related to the changes in the ohmic part of the impedance, Fig. 5(b). The change in ohmic part of the impedance is possibly related to loss of (electric) contact at the various interfaces between interconnects and electrodes, see also Section 4.5. Thermomechanical stresses during endothermic steam electrolysis operation could possibly explain the occurrence of such a delamination.

It should be noted that the low-frequency intercept with the $\mathrm{x}$ axis obtained by modeling of the low-frequency arc in Fig. 5(b) is about a factor of 1.5 larger than the ASR measured at low current densities in Fig. 4(b). This is possibly due to an inaccurate measurement of the impedance shunt resistance. However, this will only affect the overall magnitude of the impedance, whereas the relative size and shape of the measured impedance spectra remains valid.

Similar to previous tests the summit frequency $f_{s}$ of the gas conversion arc [29] (low frequency part, Fig. 5(a)) decreases with increasing pressure $[14,23]$. The summit frequency vs. pressure obtained from the modelling is presented in Fig. 13. It should be noted that gas conversion at both the fuel and the air electrode contribute to the gas conversion impedance arc and consequently to the measured summit frequency.

Based on the ideal gas law, a $P^{-1}$-depencency of the summit frequency of the gas conversion arc was previously predicted for the fuel electrode [29]. A similar continuous stirred-tank reactor (CSTR)-model would predict a $P^{-1}$-depencency for the summit frequency of the oxygen (in air) conversion arc at the airelectrode. The fit shows an exponent of -0.753 . This is lower than the -0.90 exponent value obtained with a previous stack test [14]. The deviation from an exponent of -1 is possibly related to decreasing gas flow-uniformity with increasing pressure, i.e. higher flow rates at some cells than others, and stagnant gas in cell corners.

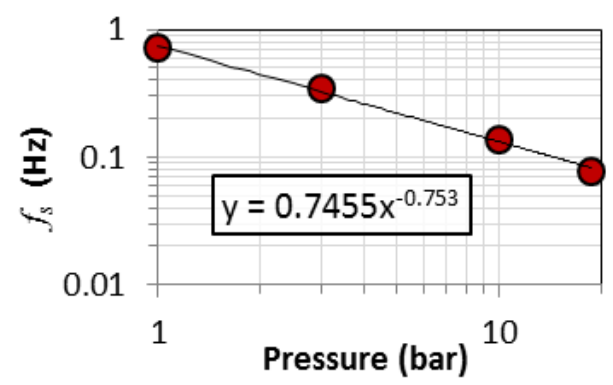

Fig. 13. Summit frequency $f_{s}$ for the gas conversion arc as function of pressure. The line represents the best fit using the expression in the figure.

For a constant molar flow rate (NLH) the resistance related to gas conversion impedance is predicted to be independent of pressure [29]. As expected the size of the gas conversion arc, see Fig. 5(b), is seen to be relatively independent of pressure.

\subsection{Internal Methanation in the Stack}

The methane concentration in the stack outlet gas clearly increases with increasing pressure, Fig. 6. Unfortunately the stack voltage was not stable during operation at $-0.17 \mathrm{~A} \mathrm{~cm}^{-2}$. After $\sim 2$ hours of operation the current was switched off. Subsequently the OCV had dropped significantly indicating a substantial increase in the internal leaks. The leak formation is possibly related to a low flow uniformity combined with a high total $\mathrm{CO}_{2}$ and $\mathrm{H}_{2} \mathrm{O}$ utilization of $88 \%$ at $-0.17 \mathrm{~A} \mathrm{~cm}^{-2}$. The operation conditions $\left(700{ }^{\circ} \mathrm{C}, 18.7 \mathrm{bar}\right.$, and a $\mathrm{H} / \mathrm{C}$ ratio $\left.=7\right)$ should not result in carbon formation - even with a local utilization approaching 100\%. However, if the utilization approaches $100 \%$ the YSZ may be reduced which can permanently damage the cells. Further, the higher diffusivity of $\mathrm{H}_{2}$ relative to that of $\mathrm{H}_{2} \mathrm{O}, \mathrm{CO}, \mathrm{CO}_{2}$, and $\mathrm{CH}_{4}$ could possibly decrease the $\mathrm{H} / \mathrm{C}$ ratio near the triple phase boundaries (3PBs) in the fuel electrode, which again could cause local carbon formation. As discussed below, in Section 4.5, post mortem SEM microscopy suggests coking occurred near the fuel electrode/electrolyte interface in cell areas near the fuel gas outlet of the stack.

It is not clear to what extent the lower methane content relative to the equilibrium content is dominated by oxidation of the fuel due to internal leaks or by kinetic limitations of the methane formation. However, at OCV the methane content in the outlet gas was $0.22 \%$, i.e. less than the (dry) equilibrium concentration of $1.7 \%$. This indicates that oxidation of the fuel gas via internal leaks in the stack substantially decreased the methane concentration. Besides the substantial amount of micron-scale Ni-particles in the fuel electrodes and cell supports, the SOFCMAN stack is equipped with $\mathrm{Ni}$ foam components (Fig. 1) which provides additional catalyst area for the methane formation.

\subsection{Long-term Electrolysis Test}

The constant current electrolysis operation exhibited a gradual stack voltage increase corresponding to a $14 \% \mathrm{kh}^{-1}$ degradation rate. This is comparable to a degradation rate of $\sim 12 \% \mathrm{kh}^{-1}$ for an SOFCMAN 30-cell stack tested at $-0.15 \mathrm{~A} \mathrm{~cm}^{-2}$ and $800{ }^{\circ} \mathrm{C}$ in a $\mathrm{H}_{2} / \mathrm{H}_{2} \mathrm{O}$ mixture [25]. The referenced SOFCMAN stack had LSM-YSZ air electrodes whereas the tested stack had cells with LSCF-GDC electrodes. The difference in electrodes, operation temperature and in current density clearly affects the degradation rate. Despite the high uncertainty it is encouraging that relative to ambient pressure steam electrolysis, pressurized operation with internal methane formation seems to have limited impact on the degradation rate.

At the end of the constant-current operation, the steam supply was gradually decreased. If the stack had been operating on a pure $\mathrm{H}_{2} \mathrm{O} / \mathrm{H}_{2}$ mixture, decreasing steam content would have 
increased the stack voltage. Instead the stack voltage started to decrease. When the stack voltage decreases the electrolysis operation becomes increasingly endothermic and this would decrease the gas inlet and outlet temperature. Contrary to this, the gas inlet and outlet temperature increased when the steam supply decreased. With a decreasing steam supply, the equilibrium methane concentration increases which again make the overall reaction more exothermic. This will increase the inlet and outlet gas temperature (the former via the heat exchanger).

\subsection{Fuel Cell Operation and Internal Methane Reforming}

The constant current fuel cell operation shows a degradation rate of $3.2 \% \mathrm{kh}^{-1}$. Despite the high uncertainty on the estimation of the degradation rate due to the short test period, it is interesting to compare it with degradation rates measured at ambient pressure. A degradation rate of $2.3 \% \mathrm{kh}^{-1}$ have been reported for a 5-cell SOFCMAN stack equipped with Ni-YSZ/YSZ/LSCYSZ cells when operated at ambient pressure, $700{ }^{\circ} \mathrm{C}$ and $0.4 \mathrm{~A}$ $\mathrm{cm}^{-2}$, and with $\mathrm{H}_{2}$ and air to the fuel and air electrodes respectively [26]. Obviously, the higher current density and the different air electrodes hamper a direct comparison of the degradation rates. Nevertheless, it is encouraging that the operation with a methane rich equilibrium gas show comparable low degradation rates.

Although the GC measurements are very uncertain it is clear that the $\mathrm{CH}_{4}$ concentration decreases with increasing fuel cell current density which confirm internal reforming. The $\mathrm{CH}_{4}$ concentration seems to decrease less with increasing current density than what would be expected if the gas reached equilibrium. This could indicate that $\mathrm{CH}_{4}$ reforming kinetics to some extent limit the conversion and full equilibration is not obtained.

\subsection{Post-mortem SEM}

The SEM images in Fig. 11 and Fig. 12 shows four generic types of damage observed inside the stack. The damages are discussed below.

1. Contact loss. Loss of contact between IC coating and current collector layer was observed at the air side. The contact loss is possibly caused by thermomechanical stress occurring during, e.g., the endothermic $\mathrm{H}_{2} \mathrm{O}$ electrolysis operation/exothermic fuel cell operation conducted in Test Part A (Table 1). In Test Part A the air flow rate was $600 \mathrm{l} / \mathrm{h}$. Increasing the air flow rate could help reducing the curvature of the temperature gradients inside the stack, and decrease the related thermomechanical stress.

2. Vertical cracks in air electrode and electrolyte. The cracks observed in Fig. 11(c) and the inset in Fig. 11(a) indicate that the stack have been exposed to too high a mechanical compression which compromised the cell structure. The stack was sandwiched between two compression/gas manifold plates and sealed using Thermiculite ${ }^{\circledR} 866$ seals between the stack and the plates. A compression force of $300 \mathrm{~kg}$ was applied using a spring load system.
The measured OCV in Test Part A - in particular at 1 bar - was only slightly lower than the theoretical EMF (Inset, top Fig. 4). This indicates limited stack leaks in the beginning of the test. The leak in the stack - and most likely the associated vertical cracks in the electrolyte - predominantly occurred during Test Part B. Had the cracks been formed due to mechanical load on the stack, one would expect to observe a low OCV at the beginning of Test Part A.

In Test Part B small inaccuracies in the fuel gas composition could result in catalytic formation of methane/reforming when the gas enters the stack. This will cause significant changes in the local temperature inside the stack which in turn could cause mechanical stress and crack the cells. A combination of excessive mechanical compression and steep temperature gradients induced by catalytic reactions inside the stack most likely explains the high leak rate observed after Test Part B.

3. Delamination between electrolyte and fuel electrode. At the fuel gas outlet, the fuel electrode is delaminated from the electrolyte, in contrast to the inlet and middle part, Fig. 11(c) and Fig. 12(c). Comparing with Fig. 12(b) we conclude that oxidation of $\mathrm{Ni}$ or mechanical treatment during SEM sample preparation (see point 5 below) is unlikely to cause the fuel electrode to delaminate completely from the electrolyte in this fuel outlet part of the cell. Two possible origins for the observed delamination is the mechanical load on the cells and/or carbon formation during test. Carbon formation causing delamination at the electrolyte/fuel electrode interface has previously been observed in a single cell SOEC test [30]. Besides electric overpotential, flow non-uniformity (as discussion in Section 4.1) and gas diffusion constraints by, e.g., high tortuosity of the gas phase in the fuel electrode may cause local carbon formation even though the overall carbon activity is below formation threshold $[31,32]$. However, since the overall $\mathrm{H} / \mathrm{C}$ ratio was 7 , enough to avoid carbon formation at $700{ }^{\circ} \mathrm{C}$ and $18.7 \mathrm{bar}$, it is believed that preferential diffusion of $\mathrm{H}_{2}$ from the 3PBs towards the gas channels lowered the $\mathrm{H} / \mathrm{C}$ ratio near the $3 \mathrm{PBs}$. Possibly the carbon formation at the electrode/electrolyte interface also led to electrolyte crack formation. This could be part of the explanation for the low OCV after Test Part B.

4. Fuel electrode oxidation. Even though the fuel electrode in the middle part of cell 15, Fig. 11(b) and Fig. 12(b), is clearly oxidized (which can be confirmed by EDX) the adhesion between the fuel electrode and electrolyte is surprisingly intact even after the SEM sample preparation. This indicates that the fuel electrode/electrolyte interface has not weakened. In this middle part of cell 15 not only the part of the fuel electrode closest to the electrolyte is oxidized but more or less the entire fuel electrode support layer (Fig. 12(b). Middle pieces of several cells were subjected to SEM images and several of them had oxidized fuel electrodes. The oxidation is most likely related to the electrolyte cracks and associated gas leaks formed in Test Part B. 


\section{Conclusion}

A 30-cell 301 SOFCMAN stack was operated at gas pressures up to 18.7 bar.

Impedance spectra recorded during pressurization indicates loss of contact inside the stack during pressurization. Loss of contact between IC and current collector layers is confirmed by post-mortem SEM analysis. The contact loss is possibly caused by thermomechanical stresses in the stack.

The air pressure drop across the stack and heat exchangers increasingly deviates from an isentropic pressure drop above 3 bar. This possibly indicates decreasing flow uniformity with increasing pressure. The gas conversion summit frequency obtained from the impedance spectra decreases with $P^{-0.753}$, where $P$ is the total absolute gas pressure. The absolute value of the exponent is substantially smaller than 1, which further indicates limited flow uniformity at the higher pressures.

Internal $\mathrm{CH}_{4}$ formation and reforming in solid oxide fuel cells can potentially enable system conversion efficiencies (power-togas-to-power) reaching $70-80 \%$. When operating the SOFCMAN 30-cell stack with a carbonaceous gas equilibrated at $700{ }^{\circ} \mathrm{C}$ and 18.7 bar, the $\mathrm{CH}_{4}$ concentration in the stack outlet gas (after condensation of $\mathrm{H}_{2} \mathrm{O}$ ) increased from $0.22 \%$ at $\mathrm{OCV}$ to $18 \%$ at $-0.17 \mathrm{~A} \mathrm{~cm}^{-2}$. The outlet gas did not fully reach equilibrium. This is most likely related to a) partial oxidation of the fuel gas due to electrolyte crack formation during the electrolysis operation, and b) to limiting methane formation kinetics. Post mortem SEM analysis shows vertical cracks across the electrolytes. This is possibly related to excessive mechanical compression and/or local heating/cooling inside the stack due to methane formation/reforming with gases not fully equilibrated. Further, delamination was observed at the fuel gas outlet between the fuel electrode and the electrolyte. This suggests that carbon was formed at this interface. Although the $\mathrm{H} / \mathrm{C}$ ratio shouldn't allow carbon formation the $\mathrm{H} / \mathrm{C}$ ratio at the triple phase boundaries at the fuel electrode/electrolyte interface might be lower when the stack is operated in electrolysis mode, due to preferential $\mathrm{H}_{2}$ diffusion. The carbon formation and electrode delamination possibly also promoted the electrolyte crack formation.

Fuel cell operation with a $\mathrm{CH}_{4}$ rich carbonaceous gas equilibrated at $700{ }^{\circ} \mathrm{C}$ and 18.7 bar shows a decrease in the $\mathrm{CH}_{4}$ concentration when increasing the current density from $0 \mathrm{~A} \mathrm{~cm}^{-}$ 2 to $0.15 \mathrm{~A} \mathrm{~cm}^{-2}$, thus confirming internal methane reforming.

Although the test period in both electrolysis and fuel cell modes was rather short, the estimates of the degradation rates seem comparable with ambient pressure degradation rates.

\section{Nomenclature}

$\begin{array}{ll}\text { Abbreviations } & \\ \text { 3PB } & \text { Triple Phase Boundary } \\ \text { AC } & \text { Anode Current Collector } \\ \text { ASR } & \text { Area Specific Resistance } \\ \text { CC } & \text { Cathode Current Collector }\end{array}$

$\begin{array}{ll}\text { CFD } & \text { Computational Fluid Dynamics } \\ \text { CSTR } & \text { Continuous Stirred Tank Reactor } \\ \text { G2P } & \text { Gas To Power } \\ \text { GDC } & \text { Gadolinium-doped Ceria } \\ \text { GC } & \text { Gas Chromatograph } \\ \text { H/C ratio } & \text { Hydrogen/Carbon ratio } \\ \text { IC } & \text { Interconnect } \\ \text { iV curve } & \text { Current density - Voltage curve } \\ \text { kh } & \text { One thousand hours } \\ \text { LSCF } & \text { Lanthanum Strontium Cobalt Ferrite } \\ \text { LSM } & \text { Lanthanum Strontium Manganite } \\ \text { NiO } & \text { Nickel Oxide } \\ \text { NLH } & \text { Normal Liter per Hour (volumetric flow rate } \\ \text { OCV } & \text { at } 0{ }^{\circ} \text { C, 101.325 kPa) } \\ \text { SEM } & \text { Open Circuit Voltage } \\ \text { P2G } & \text { Scanning Electron Microscopy } \\ \text { SOC } & \text { Power To Gas } \\ \text { SOEC } & \text { Solid Oxide Cell } \\ \text { YSZ } & \text { Solid Oxide Electrolysis Cell } \\ & \text { Yttria Stabilized Zirconia }\end{array}$

$\begin{array}{ll}\text { Variables } & \\ d P & \text { pressure drop across the SOC stack } \\ f_{s} & \text { Summit Frequency } \\ P & \text { Total absolute gas pressure (measured in bar) } \\ T & \text { Temperature (measured in Celcius) } \\ Z, & \text { Area Specific Real part of the impedance } \\ & \text { (measured in } \Omega \mathrm{cm}^{2} \text { ) } \\ Z, & \begin{array}{l}\text { Area Specific Imaginary part of the impedance } \\ \text { (measured in } \Omega \mathrm{cm}^{2} \text { ) }\end{array}\end{array}$

Acknowledgment

The authors acknowledge financial funding from the Danish Energy Technology Development and Demonstration Program (EUDP), project no. 64015-0523 "Maturing SOEC". The authors wish to thank Yuliang Liu for providing some of the SEM images, and Bent Førster Hansen, Jens Østergaard, Jens Borchsenius, John Johnson, Martin Nørby Nielsen and Søren Koch for technical expertise and assistance in developing the test setup and running the test.

\section{References}

[1] Becker S, Frew BA, Andresen GB, Zeyer T, Schramm S, Greiner M, et al. Features of a fully renewable US electricity system: Optimized mixes of wind and solar PV and transmission grid extensions. Energy. 2014;72:443-58.

[2] Mathiesen BV, Lund H, Connolly D, Wenzel H, Østergaard PA, Möller B, et al. Smart Energy Systems for coherent 100\% 
renewable energy and transport solutions. Applied Energy. 2015;145:139-54.

[3] Ebbesen SD, Jensen SH, Hauch A, Mogensen MB. High temperature electrolysis in alkaline cells, solid proton conducting cells, and solid oxide cells. Chemical Reviews. 2014;114:10697-734.

[4] Götz M, Lefebvre J, Mörs F, McDaniel Koch A, Graf F, Bajohr S, et al. Renewable Power-to-Gas: A technological and economic review. Renewable Energy. 2016;85:1371-90.

[5] Papurello D, Lanzini A, Tognana L, Silvestri S, Santarelli M. Waste to energy: Exploitation of biogas from organic waste in a $500 \mathrm{Wel}$ solid oxide fuel cell (SOFC) stack. Energy. 2015;85:145-58.

[6] Lanzini A, Madi H, Chiodo V, Papurello D, Maisano S, Santarelli M, et al. Dealing with fuel contaminants in biogas-fed solid oxide fuel cell (SOFC) and molten carbonate fuel cell (MCFC) plants: Degradation of catalytic and electro-catalytic active surfaces and related gas purification methods. Progress in Energy and Combustion Science. 2017;61:150-88.

[7] Bossel U, Eliasson B, Taylor G. The future of the hydrogen economy: bright or bleak? Cogeneration and Competitive Power Journal. 2003;18:29-70.

[8] Jensen SH, Mogensen M. Perspectives of High temperature Electrolysis using SOEC. 19 $9^{\text {th }}$ World Energy Congress. Sydney, AU: World Energy Council; 2004.

[9] Bierschenk DM, Wilson JR, Barnett SA. High efficiency electrical energy storage using a methane-oxygen solid oxide cell. Energy \& Environmental Science. 2011;4:944-51.

[10] Wendel C, Kazempoor P, Braun RJ. Novel electrochemical energy storage system based on reversible solid oxide cells: System design and operating conditions. J Power Sources. $2015 ; 276$.

[11] Kazempoor P, Braun RJ. Model validation and performance analysis of regenerative solid oxide cells for energy storage applications: Reversible operation. Int J Hydrogen Energy. 2014;39:5955-71.

[12] Jensen SH, Graves C, Mogensen M, Wendel C, Braun R, Hughes G, et al. Large-scale electricity storage utilizing reversible solid oxide cells combined with underground storage of $\mathrm{CO}_{2}$ and $\mathrm{CH}_{4}$. Energy and Environmental Science. 2015;8:2471-9.

[13] Brabandt J, Posdziech O. System Approach of a Pressurized High-Temperature Electrolysis. Ecs Transactions. 2017;78:2987-95.

[14] Jensen SH, Sun X, Ebbesen SD, Chen M. Pressurized Operation of a Planar Solid Oxide Cell Stack. Fuel Cells. 2016;16:205-18.

[15] Wu PC, Shy SS. Cell performance, impedance, and various resistances measurements of an anode-supported button cell using a new pressurized solid oxide fuel cell rig at 1-5 atm and 750-850 degrees C. J Power Sources. 2017;362:105-14.

[16] Hughes GA, Railsback J, Butts DM, Barnett SA. Electrochemical performance of solid oxide cell oxygen electrodes under pressurization. 2015;68:687-97.

[17] Bernadet L, Laurencin J, Roux G, Montinaro D, Mauvy F, Reytier M. Effects of Pressure on High Temperature Steam and
Carbon Dioxide Co-electrolysis. Electrochimica Acta. 2017;253:114-27.

[18] Timmermann H, Sawady W, Reimert R, Ivers-Tiffée E. Kinetics of (reversible) internal reforming of methane in solid oxide fuel cells under stationary and APU conditions. J Power Sources. 2010;195:214-22.

[19] Hsieh YD, Chan YH, Shy SS. Effects of pressurization and temperature on power generating characteristics and impedances of anode-supported and electrolyte-supported planar solid oxide fuel cells. J Power Sources. 2015;299:1-10.

[20] Bernadet L, Gousseau G, Chatroux A, Laurencin J, Mauvy $\mathrm{F}$, Reytier M. Influence of pressure on solid oxide electrolysis cells investigated by experimental and modeling approach. Int $\mathbf{J}$ Hydrogen Energy. 2015;40:12918-28.

[21] Sun X, Bonaccorso AD, Graves C, Ebbesen SD, Jensen SH, Hagen A, et al. Performance characterization of solid oxide cells under high pressure. Fuel Cells. 2015;15:697-702.

[22] Santhanam S, Heddrich MP, Riedel M, Friedrich KA. Theoretical and experimental study of Reversible Solid Oxide Cell (r-SOC) systems for energy storage. Energy. 2017;141:20214.

[23] Jensen SH, Graves C, Chen M, Hansen JB, Sun X. Characterization of a planar solid oxide cell stack operated at elevated pressure. J Electrochem Soc. 2016;163:F1596-F604.

[24] Guan W, Wang WG. Electrochemical Performance of Planar Solid Oxide Fuel Cell (SOFC) Stacks: From Repeat Unit to Module. Energy Technology. 2014;2:692-7.

[25] Zheng Y, Li Q, Guan W, Xu C, Wu W, Wang WG. Investigation of 30-cell solid oxide electrolyzer stack modules for hydrogen production. Ceramics International. 2014;40:58019.

[26] Jin L, Guan W, Ma X, Zhai H, Wang WG. Quantitative contribution of resistance sources of components to stack performance for planar solid oxide fuel cells. J Power Sources. 2014;253:305-14.

[27] Bi W, Chen D, Lin Z. A key geometric parameter for the flow uniformity in planar solid oxide fuel cell stacks. Int $\mathbf{J}$ Hydrogen Energy. 2009;34:3873-84.

[28] Kee RJ, Korada P, Walters K, Pavol M. A generalized model of the flow distribution in channel networks of planar fuel cells. J Power Sources. 2002;109:148-59.

[29] Primdahl S, Mogensen M. Gas conversion impedance: A test geometry effect in characterization of solid oxide fuel cell anodes. J Electrochem Soc. 1998;145:2431-8.

[30] Tao Y, Ebbesen SD, Mogensen MB. Carbon Deposition in Solid Oxide Cells during Co-Electrolysis of $\mathrm{H}_{2} \mathrm{O}$ and $\mathrm{CO}_{2}$. Electrochemical Society Inc.; 2014.

[31] Skafte TL, Blennow P, Hjelm J, Graves CR. Carbon deposition and sulfur poisoning during $\mathrm{CO}_{2}$ electrolysis in nickel-based solid oxide cell electrodes. J Power Sources. 2017;373:54-60.

[32] Duhn JD, Jensen AD, Wedel S, Wix C. Optimization of a new flow design for solid oxide cells using computational fluid dynamics modelling. J Power Sources. 2016;336:261-71. 